\title{
Investigation the Impacts of Fuel Oil on the Geotechnical Properties of Cohesive Soil
}

\author{
Mahdi O. Karkush ${ }^{\mathrm{a}, *}$ and Zaineb Abdul Kareem ${ }^{\mathrm{b}}$ \\ Department of Civil Engineering, University of Baghdad, Iraq \\ E-mail: amahdi_karkush@coeng.uobaghdad.edu.iq (Corresponding author), bzainebkareem68@yahoo.com
}

\begin{abstract}
The present study investigates the impacts of fuel oil (MFO) on the chemical, physical and mechanical properties of cohesive soil. The contaminant is fuel oil disposed as byproduct from the fuel feeding the electricity power plant at the campus of University of Baghdad in Baghdad/Iraq. The soil sample are obtained from the same site of electricity plant and classified according to unified soil classification system (USCS) as silty clay of low plasticity (CL). The soil samples are artificially contaminated with two percentages of fuel oil, 10 and $20 \%$ in relative to the dry weight of soil. The soil samples were mixed by hands with fuel oil and left for 4 days to allow chemical reactions between soil particles and contaminant. A series of laboratory tests are conducted on both intact and artificially contaminated soil samples to measure the effects of fuel oil on the chemical, physical and mechanical properties of soil samples. The results of tests showed that the fuel oil has significant impacts on the mechanical properties of soil and slight effects on the chemical and physical properties of soil. Increasing the percentage of contaminant causes a slight decrease in the liquid limit and particle size distribution, on the other hand it causes a considerable decrease in the consolidation and shear strength parameters. The results of direct shear tests showed decreasing the cohesion of soil by 44 and $67 \%$, but the angle of internal friction decreased by 20 and $32 \%$ for soil samples contaminated with $10 \%$ and $20 \%$ of fuel oil respectively.
\end{abstract}

Keywords: Industrial wastewater, fuel oil, soil contamination, geotechnical properties, cohesive soil.

ENGINEERING JOURNAL Volume 21 Issue 4

Received 14 January 2017

Accepted 19 February 2017

Published 31 July 2017

Online at http://www.engj.org/

DOI:10.4186/ej.2017.21.4.127 


\section{Introduction}

The rapid development of industrialization and urbanization generate much higher quantities of wastewater, solid wastes and gaseous wastes which resulted in polluted the environment. These wastes are not polluted the air or water only also the soil is being polluted. The occurrences of contaminant in soil above a certain level causing loss some of the geotechnical properties of soil and consequently this lead to detriment of the structures constructed on/in it. The alteration in the geotechnical properties of soil resulted in loss some of the bearing capacity of soil and increase in the settlement of the foundation under the structure which consequently causing losing the function or failure of the structure [1]. The most common types of soil contamination are fertilizers, pesticides, petroleum hydrocarbon, heavy metals, volatile organic compounds and organic compounds. The sources of contaminants are the oil fields, thermal power plants, or in most cases the contaminants are resulted accidently from the spill of oil during the transportation as leakage from the pipelines and storage tanks or during oil drilling processes. The attention of researcher was focused on investigated the effects of such contaminants on the geotechnical properties of soil due to the large volume and types of contaminants resulted from the oil industries. Industrial wastes refer to the wastes generated from the production of industry activities, treatment and development. The industrial wastes can be solid wastes, semi-solid wastes, wastewater and gaseous wastes that are not permitted to discharge directly into the environment. The solid wastes are classified into organic and inorganic wastes based on their mineral composition and into hazardous and nonhazardous wastes based on the pollution characteristics. Large quantities of industrial wastes are generated every year due to growing of industries and these wastes are harm to the human being health and the environment components. In general, the industrial wastes are classified into the following major types [2, 3]:

a) Mining industry;

b) Metallurgical industry;

c) Electrical power industry;

d) Chemical industry;

e) Light industries;

f) Industrial solid wastes such as metal dross, plating sludge, construction wastes and slag from processing in other industries.

Soil contamination usually results from the percolation of wastes from the sanitary landfills or percolation of contaminated surface water to subsurface strata, leakage from underground storage tanks and pipes, leaching of waste direct from of industrial wastes and application of fertilizer and pesticides to soil. The occurrence of contaminations in soil are not challenge for the environmentalists only but also cause a deterioration of geotechnical properties of soil. Cohesive soils which are electro-chemically active and affected whenever the environment is contaminated by wastes $[4,5]$. The flow of contaminant in the soil or in groundwater depends on many factors such as the permeability of soil and adsorption properties of the soil solids [6]. The extent of contaminant in the soil depends on the properties of soil and chemical composition of the contaminant [7].

Abdul Rasool [8] investigated the influence of kerosene contamination on the geotechnical properties of clayey silt soil. The results showed significant effects for kerosene on the physical and mechanical properties of soil. Khamehchiyan et al. [9] investigated the geotechnical properties of clayey and sandy soils contaminated by crude oil. The results indicated noticeable reduction in the shear strength, the dry density, optimum moisture content and Atterberg's limits with increasing the content of crude oil in the soil. Karkush et al. [10] investigated the effects of four types of contaminants on the geotechnical properties of clayey soil. The four contaminants are kerosene, ammonium nitrate, copper and lead, each of them was mixed with soil in two percentages (10 and 25) \%. The results showed diverse effects for these contaminants on the geotechnical properties of clayey soil. Karkush and Resol [11] investigated the geotechnical properties of sandy soil. The soil samples were contaminated artificially with four percentages of industrial wastewater $(10,20,40$ and 100) $\%$ of solution used in the contamination process. The wastewater was a byproduct from the fuel of electricity power plant. The results of tests showed diverse effects for the industrial wastewater on the geotechnical properties of a sandy soil. George et al. [12] conducted experimental work to study the effect of diesel engine oil on the geotechnical properties of soil.

Bala et al. [13] investigated the effects of salinity on the chemical characteristics of eight soil samples from Bangladesh. They studied salinity, organic content, chloride, $\mathrm{pH}$, alkalinity, conductivity and moisture 
content. Also, they concluded that the salinity and organic content vary with depth, age and soil condition. Karkush and Abdul Kareem [14] investigated the impacts geotechnical properties of clayey soil samples contaminated by industrial wastewater. The soil samples were artificially contaminated with four percentages of industrial wastewater disposed as byproduct from the fuel of thermal electricity power plant. Uromeihy et al. [15] studied the effects of three percentages of gas oil on the geotechnical properties of poorly graded sand low plasticity clay and silt. Based on the tests results, they concluded that gas oil contamination causes decreasing the angle of internal friction and increasing the cohesion between soli particles. Also, Karkush and Altaher [16] investigated the effects of total petroleum hydrocarbons on the geotechnical properties of clayey soil samples contaminated in the field. The results showed negative effects of total petroleum hydrocarbons on the geotechnical properties of a clayey soil sample.

The present study is a trial to determine the effects of the fuel oil denoted later (MFO) on the geotechnical properties of silty clay soil. An efficient laboratory-testing program was conducted on the intact and contaminated soil samples to measure the impacts of fuel oil on the chemical, physical and mechanical properties of soil. The contaminant is a byproduct discharged from fuel used in the electricity power plant at the campus of University of Baghdad in Bagdad city/Iraq. Also, the cohesive soil samples are obtained from the same site and these soil samples were contaminated with $10 \%$ and $20 \%$ of fuel oil in related to its dry weight.

\section{Experimental Work}

The experimental work includes; a) description of study area where the soil sample and contaminant are obtained; b) the process of soil contamination; and c) the field and laboratory tests conducted on soil samples to measure the effects of fuel oil on the geotechnical properties of soil samples.

\subsection{Study Area}

The materials obtained from the study area are the contaminant and the soil samples (disturbed and undisturbed). The study area is the site of electricity power plant at the campus of University of Baghdad in Baghdad city/Iraq. The georeferencing coordinates of the site, GPS coordinates, are N: $33^{\circ} 15^{\prime} 56.424^{\prime \prime}$ and E: $44^{\circ} 22^{\prime} 49.833^{\prime \prime}$ as shown in Fig. 1.

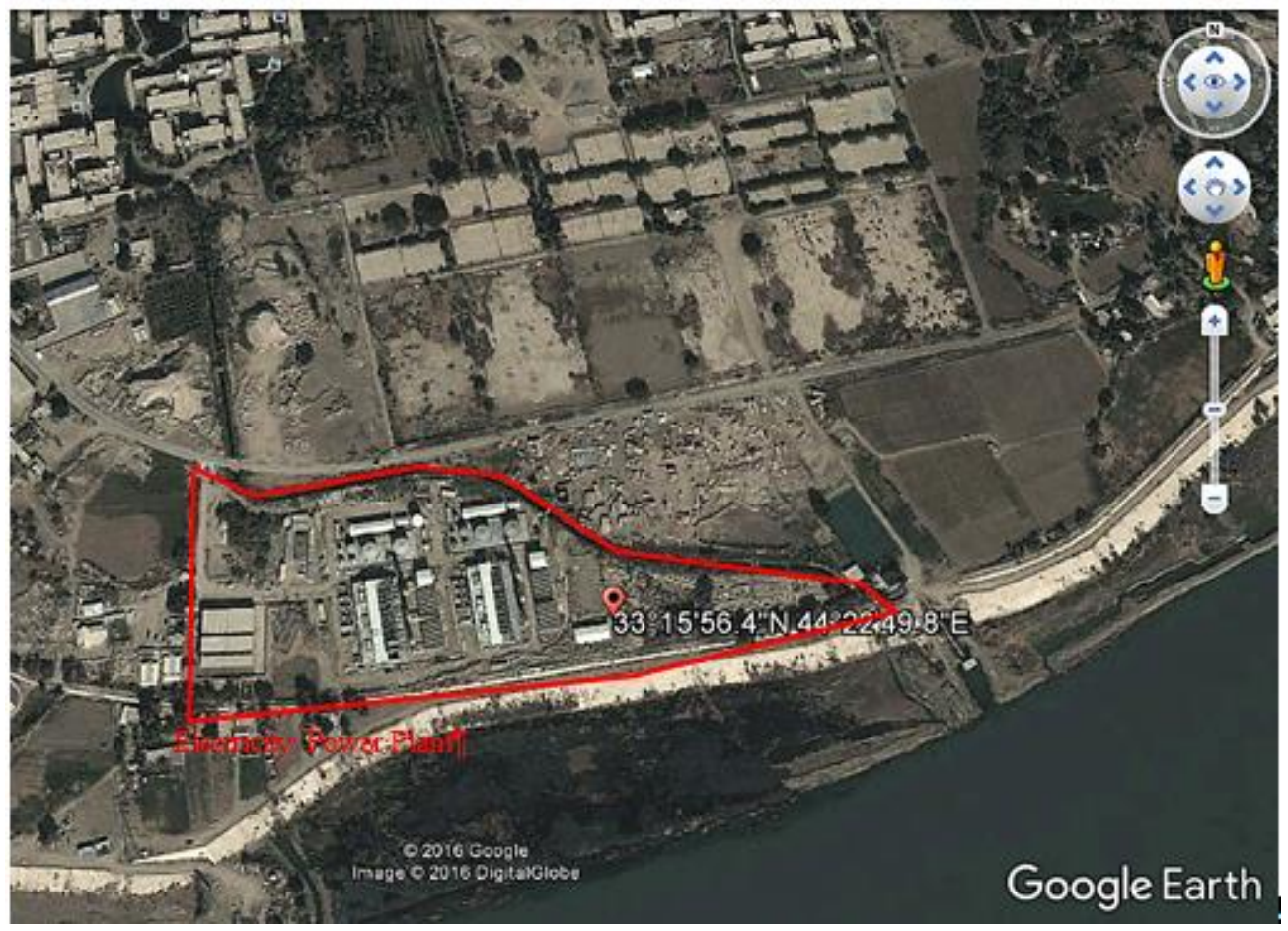

Fig. 1. Satellite image of electricity power plant at the campus of University of Baghdad. 
A trial pit was excavated by using mechanical shovel to reach the required depth of $2 \mathrm{~m}$ below the existing ground level. Disturbed and undisturbed soil samples are obtained from this trial pit, the disturbed soil samples are used to measure the effects of fuel oil on the chemical and physical properties of soil, while the undisturbed soil samples are used to measure the effects of fuel oil on the mechanical properties of soil. The soil samples were put in airtight plastic containers and labeled with necessary information, then transported to the laboratory of soil mechanics. The field unit weight of soil is $17.08 \mathrm{kN} / \mathrm{m}^{3}$ (ASTM-D2937) and the natural moisture content is $20.77 \%$ (ASTM-D2937) [17]. The contaminant used in this study is medium fuel oil denoted later as (MFO) and which is a by-product removed from the fuel oil used in feeding the electricity power plant at the campus of Baghdad University. Figure 2 shows discharging of medium fuel oil into soil in the study area. The contaminant is a mixture of water $(32 \%)$ and oil $(68 \%)$. The results of these tests are given in Table 1.

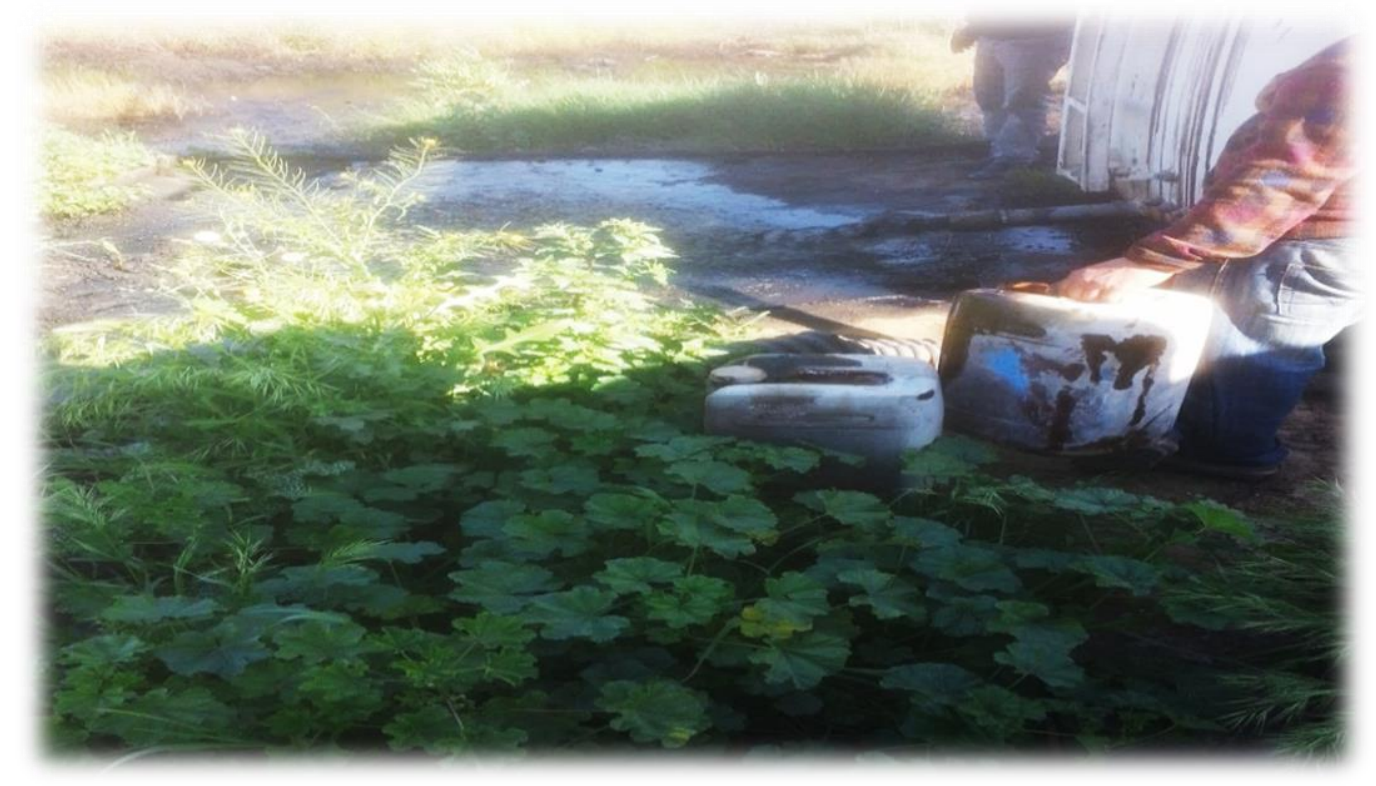

Fig. 2. Effluent of fuel oil to the soil in the study area at the campus of University of Baghdad.

Table 1. Density and chemical analysis of fuel oil (MFO).

\begin{tabular}{cccccccc}
\hline \multirow{2}{*}{$\begin{array}{c}\text { Industrial } \\
\text { Wastewater }\end{array}$} & $\begin{array}{c}\text { Density } \\
\mathbf{k g} / \mathbf{m}^{\mathbf{3}}\end{array}$ & \multicolumn{6}{c}{ Concentration of Minerals } \\
\cline { 3 - 8 } & & Mineral & $\mathbf{p p m}$ & Mineral & $\mathbf{p p m}$ & Mineral & $\mathbf{p p m}$ \\
\hline \multirow{3}{*}{$\mathrm{MFO}$} & \multirow{2}{*}{991.1} & $\mathrm{Na}$ & 12.23 & $\mathrm{~Pb}$ & 1.13 & $\mathrm{Cu}$ & 2.26 \\
& $\mathrm{Li}$ & 0 & $\mathrm{Si}$ & 21.09 & $\mathrm{Fe}$ & 88.26 \\
& & $\mathrm{Mg}$ & 23.13 & $\mathrm{Cr}$ & 0.85 & $\mathrm{Mn}$ & 6.45 \\
& & $\mathrm{Ca}$ & 1237.14 & $\mathrm{Ni}$ & 28.5 & $\mathrm{C}$ & 70.03 \\
\hline
\end{tabular}

The density of contaminant is $0.9911 \mathrm{~g} / \mathrm{cm}^{3}$ measured at temperature of $20.9{ }^{\circ} \mathrm{C}$. The American Petroleum Institute gravity (API gravity) is a measure of how heavy or light a petroleum liquid is compared to water. The petroleum liquid is classified light and floats on water when API gravity is greater than 10; if API gravity is less than 10, the petroleum liquid is classified heavy and sinks in water. The definition of API gravity is (ASTM, D278):

$$
\text { APIGravity, degree }=\frac{141.5}{\mathrm{SG}}-131.5
$$

Where SG is the specific gravity of petroleum liquid: 


$$
\mathrm{SG}=\frac{\gamma_{P L}}{\gamma_{w}}
$$

The density of water is $0.998203 \mathrm{~g} / \mathrm{cm}^{3}$ at temperature of $20.9^{\circ} \mathrm{C}$ (ASTM, D4052), so the specific gravity of contaminant, SG, is 0.992884 and API gravity is $11.014^{\circ}$ which is greater than 10 , so the contaminant is medium fuel oil. The density and chemical analysis of fuel oil used in the present work are conducted according to ASTM [17].

\subsection{Process of Soil Contamination}

The soil samples are mixed with two percentages of fuel oil 10 and $20 \%$ in relative to the dry weight of the soil samples used in the contamination process. The soil samples were contaminated artificially through well mixing of the contaminant with soil samples by hands in the laboratory. The soil samples kept mixed with contaminant for 4 days and the soil left for 4 days to allow chemical reactions between fuel oil and mineral composition of soil. Then, the soil samples are prepared to measure the effects of the contaminant on the geotechnical properties of soil. The process of mixing the contaminant with soil is showed in Fig. 3.
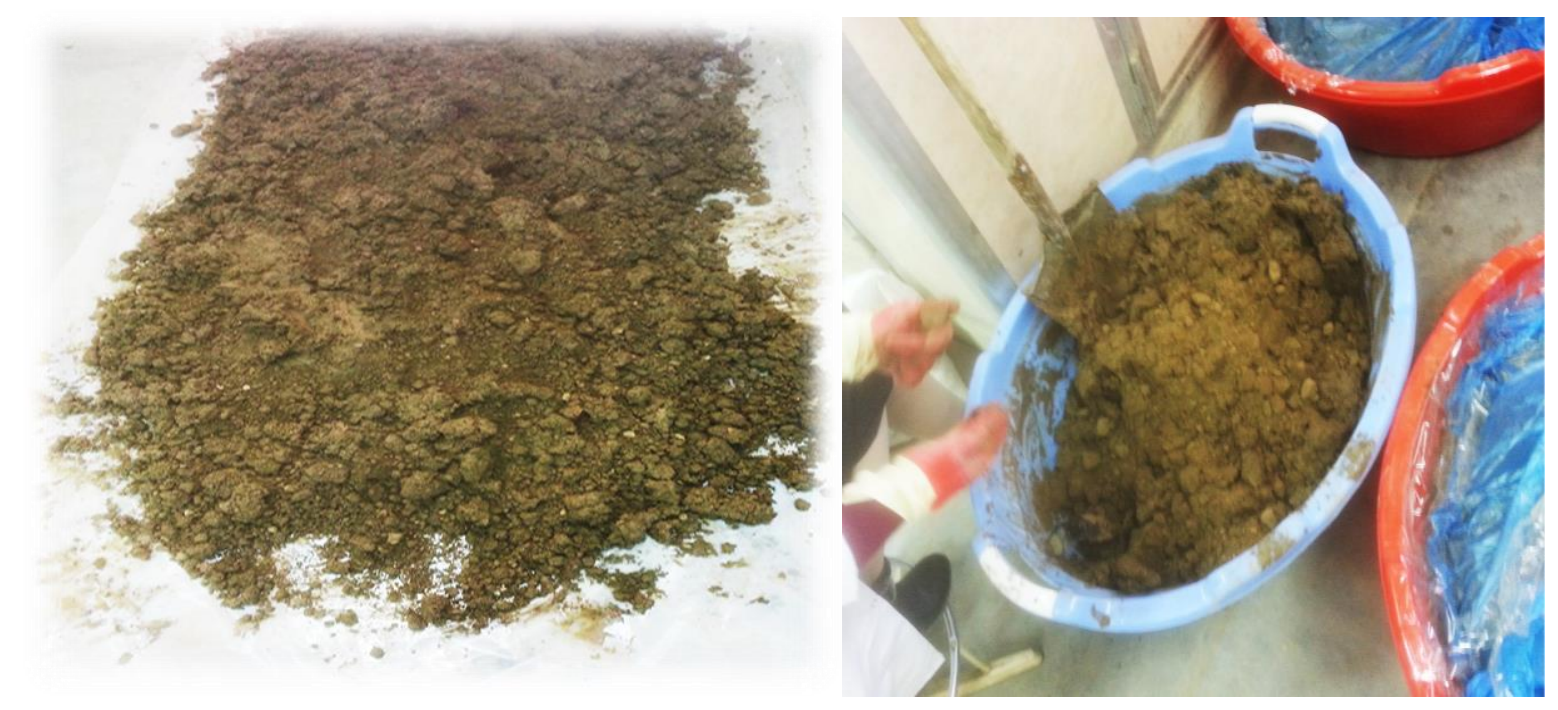

Fig. 3. Mixing the fuel oil with the soil in the laboratory of University of Baghdad.

\subsection{Soil Tests}

A specific laboratory testing program was conducted on the soil samples before contamination and after 4 days of mixing the contaminant with soil. The disturbed soil samples are used for testing the physical and chemical properties of intact and contaminated soil samples. The undisturbed soil samples are used for testing the mechanical properties of intact soil, while remolded soil samples are used for testing the mechanical properties of contaminated soil. The remolding or constituting of soil samples are based on the field unit weight and natural moisture content. The soil samples studied in this work are designated as follows: intact soil is MFO0, soil sample contaminated with 10\% of fuel oil is MFO1 and soil sample contaminated with $20 \%$ of fuel oil is MFO2. The soil tests carried out in this research can be divided into three major groups: chemical tests; physical tests and mechanical tests.

\subsubsection{Chemical tests}

The chemical properties of soil samples play an important role in the engineering behavior of cohesive soils. The chemical and $\mathrm{x}$-ray diffraction tests are carried out on the disturbed intact and contaminated soil samples $[17,18]$. The following chemical tests are conducted on intact and contaminated soil samples:

a) $\mathrm{pH}$ value, this test is conducted according to ASTM (D4972).

b) Three sulfate ions $\left(\mathrm{SO}_{3}\right)$, this test is conducted according to ASTM (D516). 
c) Chloride content $\left(\mathrm{Cl}^{-1}\right)$, this test is conducted according to ASTM (D512 A).

d) Total dissolved solids (TDS) and total suspended solids (TSS) are conducted according to ASTM (D5907)

e) Calcium carbonate content $(\mathrm{CaO})$, this test is conducted according to ASTM (D4373-02).

f) Sodium content $(\mathrm{Na})$, this test is conducted according to ASTM (D4191-03).

\subsubsection{Physical tests}

Features of the soil profile and the soil horizons are often described in the field in terms of the soil's physical properties $[17,18]$. The major physical properties of soil samples measured in this work are:

a) Specific gravity (Gs), this test is conducted according to ASTM (D854).

b) Particle size distribution, this test is conducted according to ASTM (D422).

c) Liquid limit (LL) and plastic limit (PL), these tests are conducted according to ASTM (D4318).

\subsubsection{Mechanical tests}

The bearing capacity of soil and compressibility of soil are often described in terms of the mechanical properties of soil. The mechanical tests conducted on the undisturbed intact and remolded contaminated soil samples. The entire mechanical tests are carried out according to ASTM [17, 19, 20].

a) 1-D consolidation test, oedometer test, this test is conducted according to ASTM (D2435).

b) Unconsolidation undraiend triaxial test, UUT, this test is conducted according to ASTM (D2166).

c) Direct shear test, DST, this test is conducted according to ASTM (D3080).

d) Unconfined compressive test, UCT, this test is conducted according to ASTM (D2166).

\section{Results and Discussions}

\subsection{Chemical Properties of Soil}

The results of chemical and $\mathrm{x}$-ray diffraction tests are given Tables 2 and 3. Some of the chemical suffering slight decrease or increase with increasing the percentage of contaminant in the soil such as Na, TSS, TDS and $\mathrm{CaO}$. The sulfur trioxide increases by $180 \%$ and $603 \%$ in the soil samples MFO1 and MFO2 respectively. The chemical reactions between the mineralogical composition of soil and fuel oil produced sulfate ion which causes increasing the percentage of sulfur trioxide. Also, the value of $\mathrm{pH}$ increased by $7 \%$ and $40 \%$ in the soil samples MFO1 and MFO2 respectively. This increase in $\mathrm{pH}$ value may be attributed to the aggravate salinization of the surface and subsurface of contaminated soil strata by the fuel oil [21]. Also, the fuel oil causes increasing the accumulative of exchangeable bases such as $\mathrm{Na}$ or $\mathrm{Ca}$ in the soil which resulted in a reduction in the exchangeable acidity and affect the cations exchange capacity [22].

Table 2. Results of chemical tests.

\begin{tabular}{cccccccc}
\hline Soil Sample & $\mathbf{S O}_{\mathbf{3}}, \boldsymbol{\%}$ & $\mathbf{N a}, \mathbf{\%}$ & $\mathbf{C l}^{-1}, \mathbf{\%}$ & TSS, \% & TDS, \% & $\mathbf{C a O}, \mathbf{\%}$ & $\mathbf{p H}$, value \\
\hline MFO0 & 0.26 & 0.79 & 0.15 & 3.1 & 0.72 & 18.75 & 5.0 \\
MFO1 & 0.73 & 0.72 & 0.16 & 2.4 & 0.65 & 17.89 & 5.35 \\
MFO2 & 1.83 & 0.97 & 0.36 & 2.5 & 0.51 & 16.02 & 7.0 \\
\hline
\end{tabular}

Table 3. Results of x-ray diffraction tests.

\begin{tabular}{ccccccc}
\hline Soil & \multicolumn{6}{c}{ Minerals, \% } \\
\cline { 2 - 7 } Sample & Quartz & Calcite & Orthoclase & Montmorillonite & Feldspar & Dolomite \\
\hline MFO0 & 27 & 14 & 7 & 25 & 21 & 7 \\
MFO1 & 32 & 20 & 9 & 9 & 11 & 4 \\
MFO2 & 20 & 22 & 1 & 6 & 47 & 3 \\
\hline
\end{tabular}




\subsection{Physical Properties of Soil}

The summary of physical properties of soil samples tested in this work is given in Table 4. Based on these results, increasing the percentage of contaminant causes a significant decrease in the values of specific gravity (Gs) due to the low density of contaminant, otherwise the contaminant leads to a slight decrease in the percentage of fine particles because of formation of soil clods. Also, in hydrometer test the salts cover the soil particles will dissolve in water and this action depends on the solubility of existing salts in water. The particle size distribution curves of tested soil samples are shown in Fig. 4. The fuel oil causes slight decrease in the liquid limit (LL) due to participation of fuel oil in coating the surfaces of solid particles, but the fuel oil causes slight increase in the plastic limit (PL) of soil due to the viscosity of such contaminant. The first contact of the fuel oil will be with the soil particles and not with the water due to the immiscibility of petroleum products with water. The liquid and plastic limits are the moisture contents where the soil at which will deform as liquid or plastic respectively. The contamination of soil with fuel oil will increase the deformation of soil due to decreasing the liquid limit of soil.

Table 4. Physical properties of soil samples.

\begin{tabular}{cccccc}
\hline Soil Sample & Gs & Sand, \% & Silt and Clay, \% & LL, $\%$ & PL, \% \\
\hline MFO0 & 2.68 & 7.25 & 92.75 & 33 & 11 \\
MFO1 & 2.53 & 9.79 & 90.21 & 32 & 15 \\
MFO2 & 2.45 & 10.34 & 89.66 & 30 & 17 \\
\hline
\end{tabular}

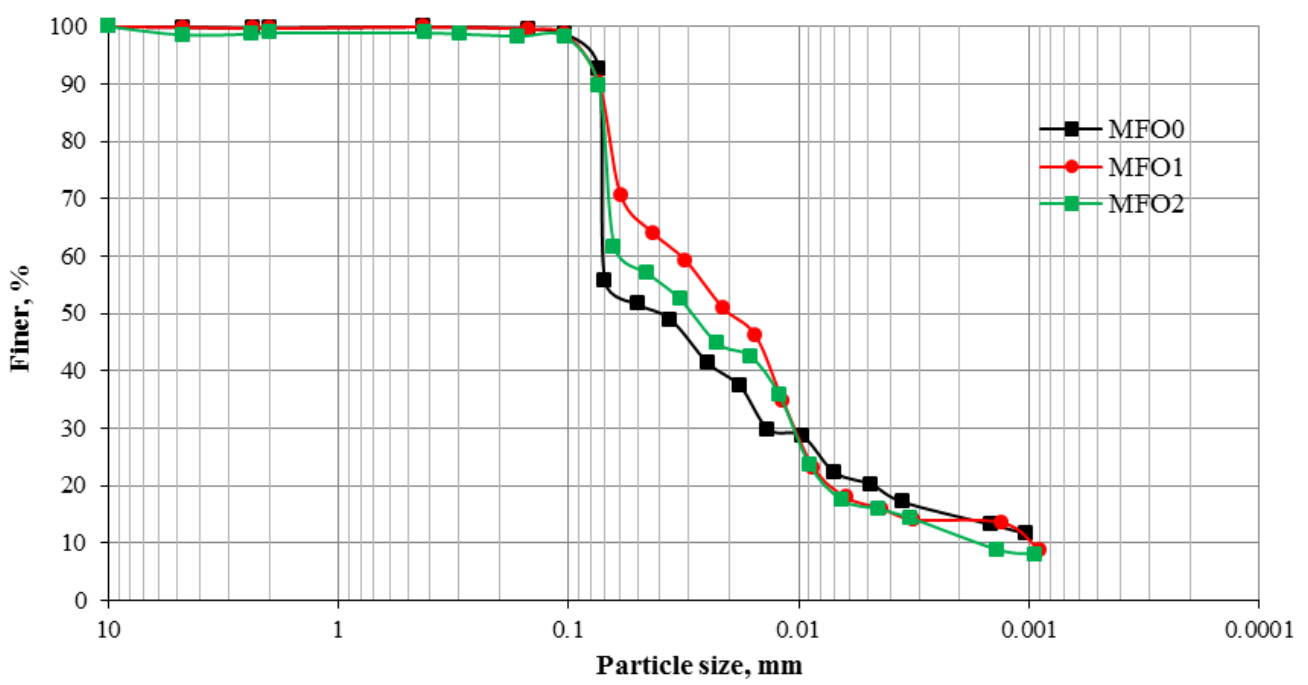

Fig. 4. Particle-size distribution curves of intact and contaminated soil samples.

\subsection{Mechanical Properties of Soil}

The results of mechanical properties of soil samples prove that the fuel oil contaminant has considerable effects on the compressibility and shear strength of soil. From the results of consolidation test, it was noticed a significant increasing in the initial void ratio $\left(\mathrm{e}_{\mathrm{o}}\right)$, the coefficient of volumetric change $\left(\mathrm{m}_{\mathrm{v}}\right)$ and the coefficient of permeability $(\mathrm{k})$, but a slight decreased was notice in the coefficient of consolidation $\left(\mathrm{c}_{\mathrm{v}}\right)$. The initial void ratio was increased by $18.5 \%$ and $37 \%$ for soil samples MFO1 and MFO2 respectively. Increasing of the initial void ratio resulted from decreasing the percentage of fines as they were bonded to form pseudo-sand and sand sized particles which created large void space between soil particles. Also, the lubricant role of fuel oil helps in slipping of the particles of soil each over other. The soil sample MFO2 sowed less effect for the contaminant on the coefficient of volumetric change and the coefficient of permeability than that of soil sample MFO1. This action may be resulted from the rearrangement of new bonds among the soil particles into macro voids to presence of fewer voids as more bonded soil matrix was formed with higher oil content in the contaminated soil. The results of 1-D consolidation tests are given in Table 5 and Fig. 5. 
Table 5. Results of mechanical properties of soil samples.

\begin{tabular}{|c|c|c|c|c|c|c|c|c|c|c|c|}
\hline \multirow{2}{*}{$\begin{array}{c}\text { Soil } \\
\text { Sample }\end{array}$} & \multicolumn{7}{|c|}{ 1-D Consolidation } & \multirow{2}{*}{$\begin{array}{c}\text { UUT } \\
\mathbf{c}_{\mathrm{u}} \\
\mathbf{k P a}\end{array}$} & \multirow{2}{*}{$\begin{array}{c}\mathrm{UCT} \\
\mathrm{c}_{\mathrm{u}} \\
\mathrm{kPa}\end{array}$} & \multicolumn{2}{|c|}{ DST } \\
\hline & $\mathbf{e}_{\mathrm{o}}$ & $e_{f}$ & Cc & Cs & $\begin{array}{c}\mathrm{m}_{\mathrm{v}} \times 10^{-3} \\
\mathrm{~m}^{2} / \mathrm{kN}\end{array}$ & $\begin{array}{c}\mathrm{k} \times 10^{-9} \\
\mathrm{~cm} / \mathrm{s}\end{array}$ & $\begin{array}{c}\mathrm{c}_{\mathrm{v}} \times 10^{-7} \\
\mathrm{~cm}^{2} / \mathrm{s}\end{array}$ & & & $\begin{array}{c}\mathrm{c} \\
\mathrm{kPa}\end{array}$ & $\begin{array}{c}\varphi \\
\text { degree }\end{array}$ \\
\hline MFO0 & 0.54 & 0.49 & 0.274 & 0.054 & 0.501 & 5.76 & 2.800 & 22 & 35 & 66 & 37 \\
\hline MFO1 & 0.64 & 0.50 & 0.283 & 0.055 & 0.531 & 5.93 & 4.335 & 21 & 29.5 & 37 & 29.5 \\
\hline MFO2 & 0.74 & 0.53 & 0.320 & 0.066 & 0.970 & 6.77 & 4.660 & 18.5 & 25 & 22 & 25 \\
\hline
\end{tabular}

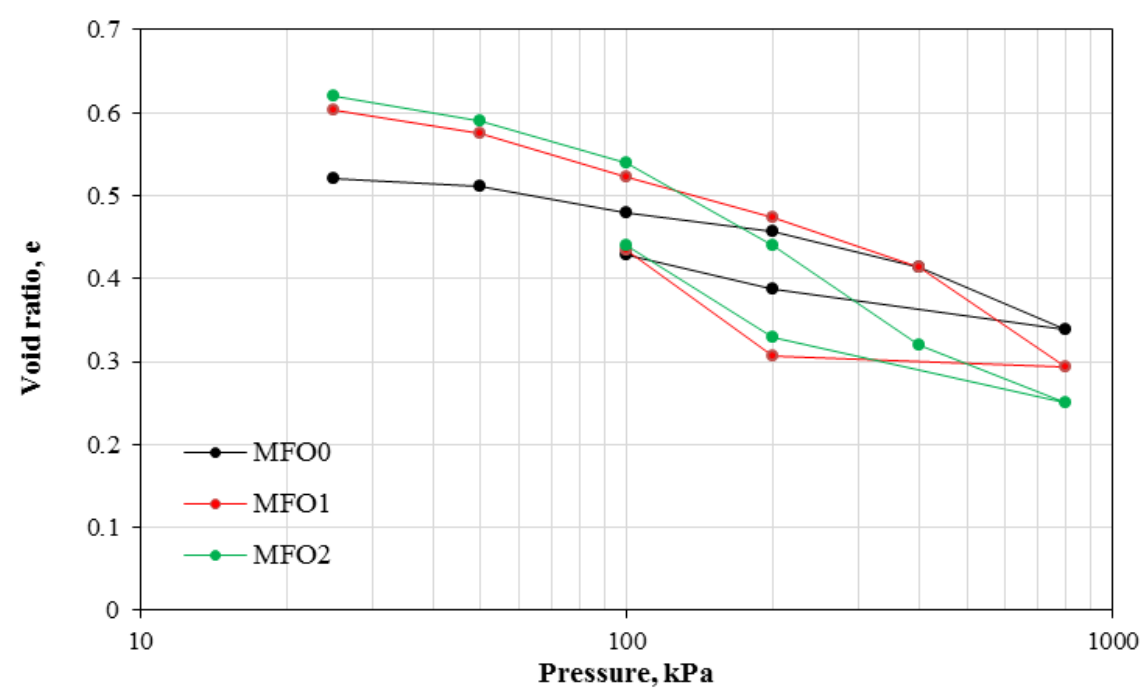

Fig. 5. Void ratio versus log of pressure of intact and contaminated soil samples.

The fuel oil contamination causes reduction in the cohesion (c) and angle of internal friction $(\varphi)$ of soil. The lubrication property of fuel oil helps in sliding the soil particles each one over others and consequently the weak bonding between the soil particles causes a significant reduction in the shear strength parameters of soil. A summary of shear strength tests is given in Table 5. The results of direct shear tests showed decreasing the cohesion of soil by 44 and $67 \%$, but the angle of internal friction decreased by 20 and $32 \%$ for soil sample MFO1 and MFO2 respectively as shown in Fig. 6. It's noticed that fuel oil contamination has more effects on cohesion rather than friction between soil particles. This behavior may be attributed to the coating of the surface of soil solids with fuel oil that causes reduction in bonding between particles and slipping of solid particles.

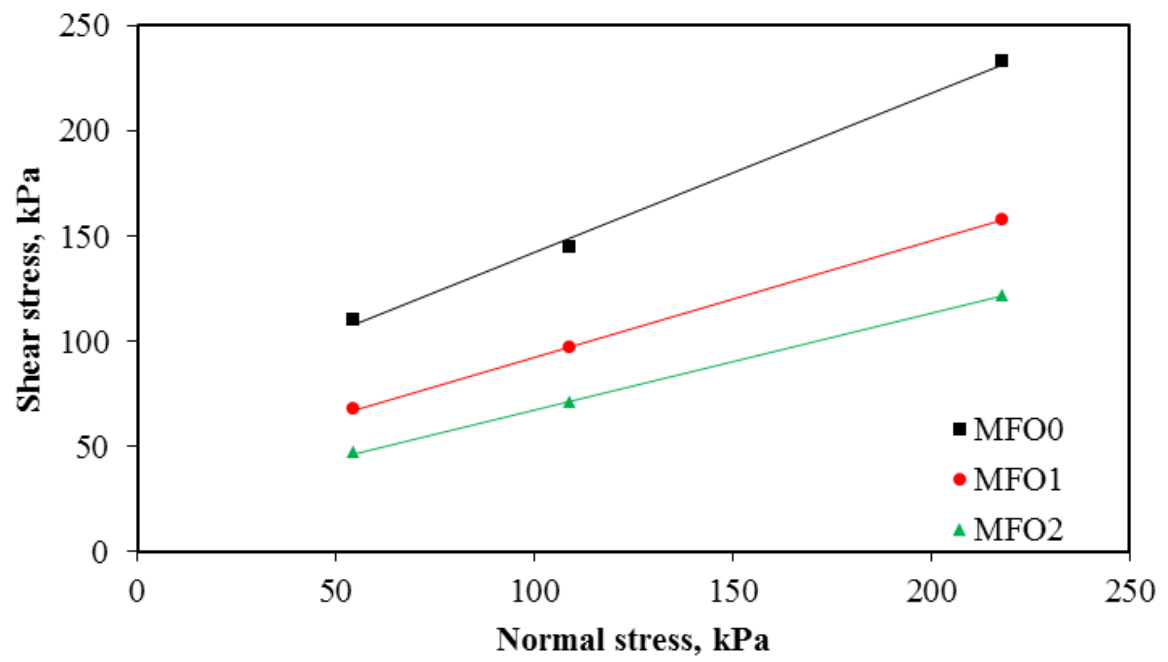

Fig. 6. Normal stress versus shear stress of direct shear tests. 
The results of unconsolidated undrained triaxial tests conducted on the soil samples at three levels of stress 100,200 and $300 \mathrm{kPa}$ showed a slight reduction in the undrained shear strength of soil. The undrainded shear strength $\left(\mathrm{c}_{\mathrm{u}}\right)$ of soil decreased by 4.5 and $16 \%$ for soil sample MFO1 and HOF2 respectively as shown in Fig. 7. The results of unconfined compressive tests showed decreasing the undrained shear strength $\left(\mathrm{c}_{\mathrm{u}}\right)$ by 15.7 and $28.5 \%$ for soil samples MFO1 and MFO2 respectively. This reduction was corresponding to a large reduction in strain by 73 and $76 \%$ for soil sample MFO1 and MFO2 respectively as shown in Fig. 8.
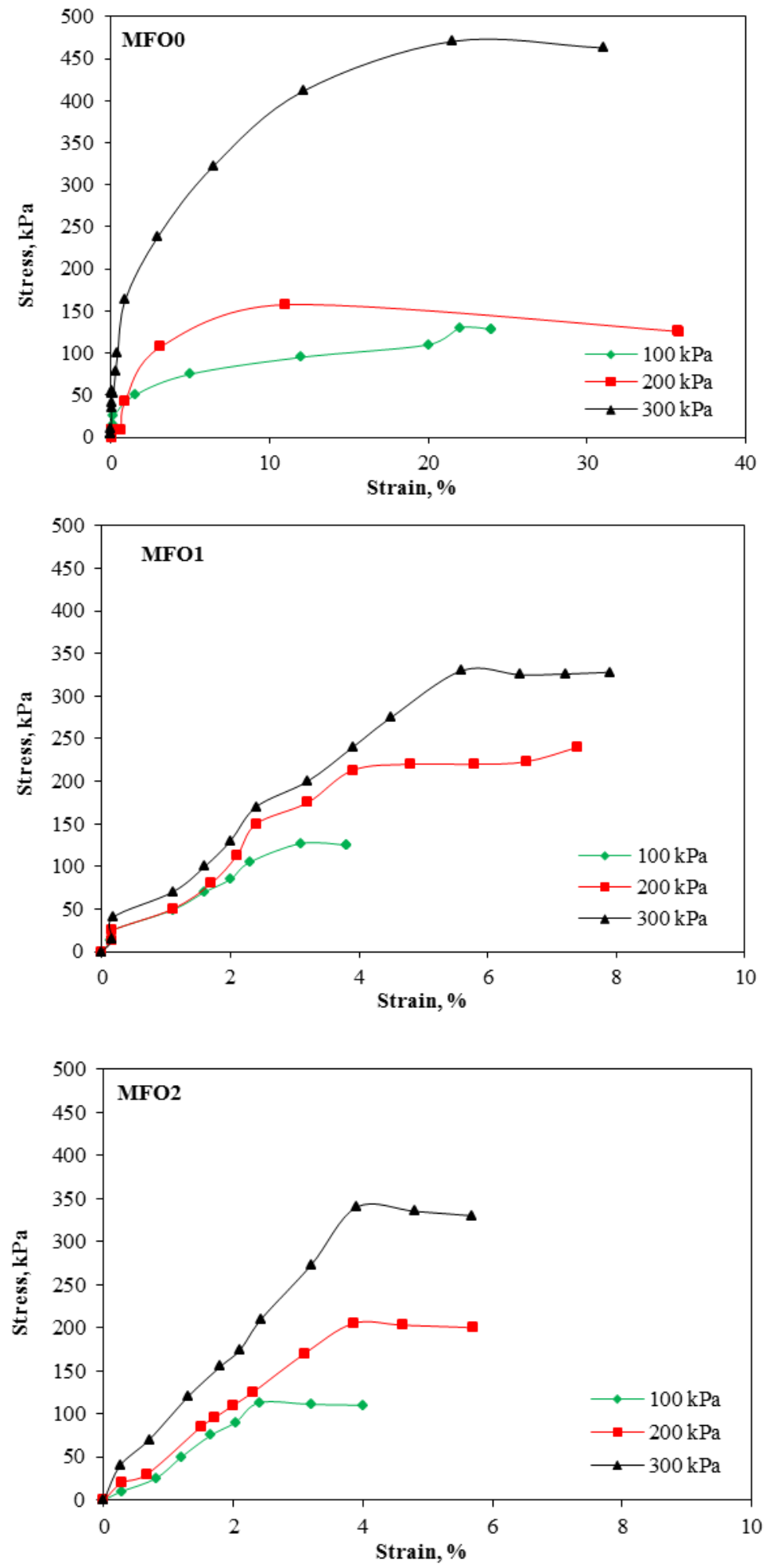

Fig. 7. Stress versus strain of unconsolidated undrained triaxial tests. 


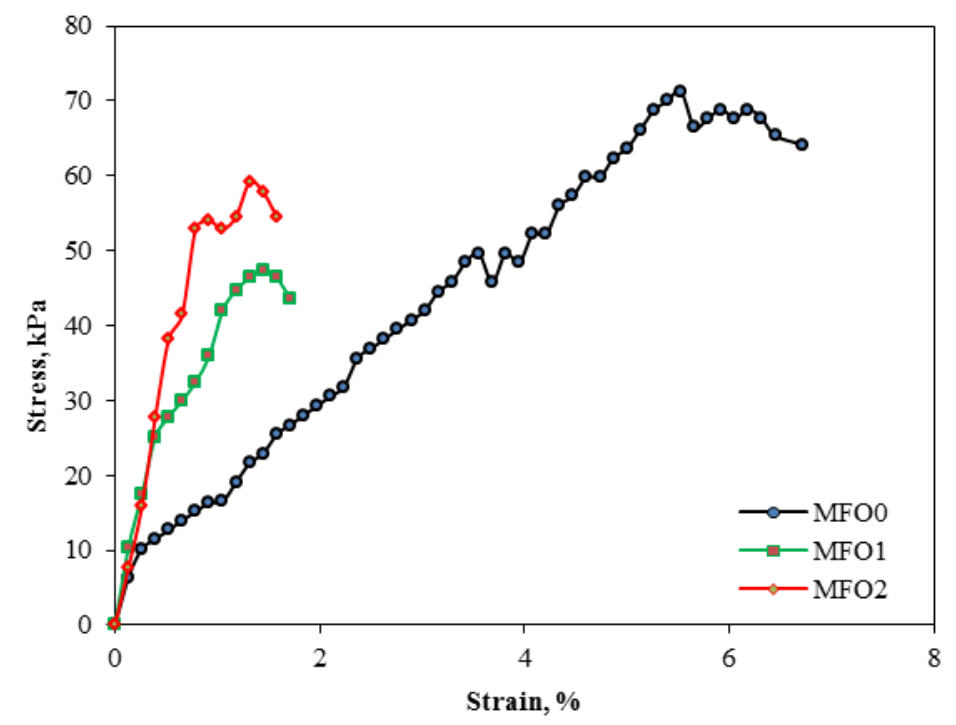

Fig. 8. Stress-strain curve of unconfined compressive tests.

\section{Conclusions}

The fuel oil has negative impacts on the geotechnical properties of cohesive soil and these effects increase with increasing the percentage of soil contamination with fuel oil. Based on the results of this work, the following actions are noticed: decreasing the specific gravity of soil, slight decrease in the liquid limit and slight increase in the plastic limit and slight reduction in the percentage of fine particles. Also, the fuel oil contamination causes increasing the initial void ratio, coefficient of volume compressibility, the coefficient of permeability and the coefficient of consolidation. The effects of fuel oil contamination on the shear strength parameters depend on the type of test and concentration of fuel oil in the soil. The direct shear test was affected significantly by fuel oil contamination and less effect was noticed in the soil samples tested by unconfined compressive test and unconsolidated undrained triaxial test. The results of unconfined compressive tests showed decreasing the undrained shear strength $\left(\mathrm{c}_{\mathrm{u}}\right)$ by 15.7 and $28.5 \%$ and the corresponding strains by 73 and $76 \%$ for soil samples MFO1 and MFO2 respectively. The results of direct shear tests showed decreasing the cohesion of soil by 44 and $67 \%$ for soil sample MFO1 and MFO2 respectively. While, the cohesion of soil samples tested by UUT is decreased by 4.5 and $16 \%$ for the soil sample MFO1 and MFO2 respectively. The important of this study raised from the wide spreading of petroleum products all around the world and effluent of such product to the soil directly by accident or due to the unavailability of treatment unit. To understand the behavior of soil contaminated with petroleum products, it's important to study the micromechanics relationship between solid particles and chemical components of contaminant.

\section{References}

[1] Z. A. Rahman, U. Hamzah, and M. R. Taha, "Influence of oil contamination on geotechnical properties of basaltic residual soil," American Journal of Applied Sciences, vol. 7, no. 7, pp. 954-961, 2010.

[2] J. Li. Types, Amounts and Effect of Industrial Solid Wastes. Point Sources of Pollution: Local Effects and Its Control, vol. 1. [Online]. Available: https://www.eolss.net/Sample-Chapters/C09/E4-11-02-03.pdf, Accessed on: 14 January 2017.

[3] H. Shi. Industrial Wastewater-Types, Amounts and Effects. Point Sources of Pollution: Local Effects and Its Control, vol. 1. [Online]. Available: https://www.eolss.net/sample-chapters/c09/e4-11-02-02.pdf, Accessed on: 14 January 2017.

[4] H. U. Rehman, S. N. Abduljauwad, and T. Akram, "Geotechnical behavior of oil contaminated finegrained soils,” Electronic Journal of Geotechnical Engineering, vol. 12, Bundle. A, 0720, 2007. 
[5] A. T. Elisha, "Effect of crude oil contamination on the geotechnical properties of soft clay soils of Niger delta region of Nigeria," Electronic Journal of Geotechnical Engineering, vol. 17, Bund. M, pp. 19291938, 2012.

[6] N. S. Nudelman, I. S. Rio, and O Katusich, "Fate of the oil residuals in Patagonian soils effects of the environmental exposure time," J. Environ. Assessment Remediation, vol. 3, pp. 1-8, 2002.

[7] P. Fine, E. R. Graber, and B. Yaron, "Soil interactions with petroleum hydrocarbons: Abiotic processes," Soil Technology, vol. 10, pp. 133-153, 1997.

[8] H. Abdul Resol, "Some geotechnical properties of oil contaminated soil," M.Sc. thesis, Department of Civil Engineering, College of Engineering, University of Baghdad, Baghdad, 1999.

[9] M. Khamehchiyan, A. M. Charkhabi, and M. Tajik, "Effects of crude oil contamination on geotechnical properties of clayey and sandy soils," Engineering Geology, vol. 89, pp. 220-229, 2007.

[10] M. O. Karkush, A. T. Zaboon, and H. M. Hussien, "Studying the effects of contamination on the geotechnical properties of clayey soil," in Coupled Phenomena in Environmental Geotechnics. London: Taylor \& Francis, 2013, pp. 599-607.

[11] M. O. Karkush and D. J. Resol, "Remediation of sandy soil contaminated with industrial wastewater," International Journal of Civil Engineering, vol. 15, no. 3, pp. 441-449, 2017.

[12] S. George, E. A. Aswarthy, B. Sabu, N. P. Krishnaprabha, and M. George, "Study on geotechnical properties of diesel oil contaminated soil," International Journal of Civil and Structural Engineering Research, vol. 2, no. 2, pp. 113-117, 2015.

[13] A. K. Bala, Q. H. Bari, A. Ahsan, M. M. ElSergany, R. Sathyamurthy, M. Ali Bek, M. K. Rowshon, J. Mallick, and N. Nik Daud, "Chemical characteristics of native soil in Shrimp Gher and agricultural land," Engineering Journal, vol. 20, no. 2, pp.1-15, 2016.

[14] M. O. Karkush and M. S. Abdulkareem, "Behavior of pile group subjected to cyclic lateral loading in contaminated soils," International Journal of Geomate, vol. 10, no. 2, pp.1943-1949, 2016.

[15] A. Uromeihy, M. R. Nikudel and A. Morsali, "Influence of gas oil contamination on geotechnical properties of fine and coarse-grained soils," Geotechnical and Geological Engineering, vol. 34, no. 1, 2016.

[16] M. O. Karkush and T. A. Altaher, "Geotechnical evaluation of clayey soil contaminated with industrial wastewater," Archives of Civil Engineering, vol. 63, no. 1, 2017.

[17] ASTM, Annual Book of Standards-Soil and Rock; Building; Stone. Peats, John Wiley \& Sons, 2003.

[18] K. M. Head, Manual of Soil Laboratory Testing, 3rd ed, vol. I, Scotland, UK: Whittles, 2006.

[19] K. M. Head, Manual of Soil Laboratory Testing, 2nd ed, vol. II. Hoboken, New Jersey: John Wiley \& Sons, 1994.

[20] K. M. Head, Manual of Soil Laboratory Testing, 4th ed, vol. III. UK: John Wiley \& Sons, 1992.

[21] M. O. Benka-Coker and J. A. Ekundayo, "Effects of an oil spill on soil physic-chemical properties of a spill site in the Niger delta area of Nigeria," Environmental Monitoring and Assessment, vol. 36, no. 2, pp. 93-104, 1995.

[22] K. Njoku, M. Akinola, and B. Oboh, "Phytoremediation of crude oil contaminated soil: The effect of growth of glycine max on the physico-chemistry and crude oil contents of soil," Nature and Science, vol. 7, no. 10, pp. 79-87, 2009. 